\title{
Study on the Protection, Inheritance and Development of Jingdezhen Ceramic Culture in the New Period
}

\author{
Aiping Zhou \\ (Jingdezhen Ceramic Institute, Jingdezhen ,Jiangxi,333000)
}

Keywords: New Era; Jingdezhen Ceramic Culture; Protection; Inheritance

\begin{abstract}
The Chinese porcelain art has a long history. Among them, the Jingdezhen ceramics are exquisite and famous overseas, and Jingdezhen is titled as a "Ceramic Capital", and the ceramic culture has become the characteristic culture of Jingdezhen. Jingdezhen ceramic culture, as a representative achievement of Chinese ceramic culture, occupies a decisive position, leaving its profound influence on the history of Chinese ceramics development. In the new era, General Secretary Xi Jinping calls for vigorous efforts to develop cultural self-confidence and demonstrate China's profound historical and cultural heritage. Therefore, from the perspective of history and the current, it is particularly important to protect and inherit the Jingdezhen ceramic culture.

In the report of the $19^{\text {th }}$ NPC, General Secretary Xi Jinping pointed out that "Culture is the soul of a country and a nation. Prospering culture brings the prosperity of a country, and strong cultural power can make a country strong. Without a high degree of cultural self-confidence and cultural prosperity, there will be no great rejuvenation of the Chinese nation." The Chinese civilization, one of the four ancient civilizations, has a long history and cultural heritage without any faults. Excellent traditional culture emerges in an endless stream. Among them, China is famous both at home and abroad for its outstanding beauty in ceramic arts. ${ }^{[1]}$ Therefore, ceramic culture is one of the Chinese culture. But when it comes to ceramic culture, there is no way to go around the "Ceramic Capital" - Jingdezhen. With the passage of time, ceramics are no longer just life utensils and handicrafts but are gradually having the unique aesthetic value, scientific value, historical value, etc., reflecting the characteristics of the era and the pursuit of values at that time, forming a unique ceramic culture. In the long history of the Chinese ceramic culture, Jingdezhen's ceramic culture is particularly beautiful and splendid among numerous treasures. ${ }^{[2]}$ In the new era, the Communist Party emphasizes the exploration of traditional Chinese culture and promotes the cultural confidence of the Chinese nation. The protection and inheritance of the Jingdezhen ceramic culture conforms to the theme of the times and closely follows the requirements of the times. This move is not only conducive to the economic development of Jingdezhen, but also conducive to conveying the Chinese impression to the world, spreading Chinese culture, and developing the Chinese economy, which is conducive to realizing the great dream of rejuvenation of the Chinese nation. In addition, the excavation, protection and inheritance of Jingdezhen ceramics culture is a global asset. In places, in China and in the world. It is a favorable move for local governments, China, and the world. It is a multi-win strategy.
\end{abstract}

\section{The Necessity of Protecting and Inheriting Ceramic Culture in Jingdezhen}

Jingdezhen ceramic culture is very representative. Jingdezhen was originally named Changnan Town because of its superb porcelain craftsmanship. In the Jingde Year, Song Zhenzong gave the town the title and renamed Jingdezhen. After the change of name, Jingdezhen ceramics is mostly dedicated to the palace. The porcelain craftsmanship is even more superb. The production process is more rigorous with more stringent requirements for finished porcelain. Often only one of the most perfect works is used in a kiln, and even the entire kiln gives up to guarantee the quality of porcelain. ${ }^{[3]}$ Therefore, the Jingdezhen ceramic culture is one of the most representative miniatures of Chinese ceramic culture.

Requirements for Cultural Self-confidence Construction in the New Era. At present, China is in a critical period of reform and the overseas situation undergoing profound and complicated changes. To realize the dream of the great rejuvenation of the Chinese nation requires all 
undertakings to go hand in hand, and we need to make unremitting efforts. In terms of cultural undertakings, we must adhere to the path of socialist cultural development with Chinese characteristics, strive to discover China's outstanding traditional culture, actively promote the development of cultural undertakings and cultural industries, and strive to increase cultural confidence and increase China's influence. Ceramic culture, as one of China's traditional fine cultures, is a kind of local characteristic culture of Jingdezhen. Its protection is particularly important and should be the focus of the government.

There are Till Defects in the Inheritance and Protection of Jingdezhen Ceramics Culture. First of all, Jingdezhen ceramics culture, as a treasure of traditional Chinese culture, has gradually been recognized by the world for its importance, and its production skills have been included in the list of intangible cultural heritage. However, with continuous promotion and recognition, Jingdezhen will become more and more popular. Due to its lucrative profits, fake and inferior porcelain has gradually appeared in the market, which constantly plagiarized Jingdezhen porcelain designs, imitated trademarks, etc. These practices not only destroyed the Jingdezhen porcelain market, but also caused the Jingdezhen porcelain culture to be tainted. Second, after the Industrial Revolution, the world is moving toward mechanization. Under the impact of modern industrialization, the traditional pottery industry suffered a blow. Faced with the new development situation, ceramic culture is unable to cope with increasingly fierce market competition due to its lack of innovative capabilities. In the international arena, the development of ceramic culture is still dominated by the excavation of traditional culture, resulting in insufficient ceramic culture. ${ }^{[4]}$ Third, under the trend of large-scale industrialized production, people's pace of life has gradually accelerated. And traditional craftsmanship ceramics gradually fade out of people's vision. Therefore, there is a shortage of talent in the development of ceramic culture. There is not only a lack of professional porcelain talents, but also a lack of professional identification talents. The shortage of professionals has become one of the key factors restricting the development of ceramic culture. Fourth, it is still a short time since China's accession to the World Trade Organization. In the competition with the international market, it lacks relevant experience and awareness. ${ }^{[5]}$ For example, there is insufficient awareness of corresponding cultural industries, and it is hard to distinguish the nature of the cultural industry. As a result, it is difficult to form a complete ceramic cultural industrial chain, which is unfavorable for the protection and inheritance of ceramic culture.

\section{Measures to Protect and Inherit Jingdezhen Ceramic Culture}

Give full play to the government guidance and take the lead. Ceramic culture is a local feature of Jingdezhen. Local governments should make full use of this business card to create their own brand and use ceramic culture to drive the economic development of Jingdezhen and even Jiangxi. To this end, local governments should do a good job of protecting and inheriting Jingdezhen ceramic culture.

First of all, the government should play its guiding role, formulate a series of effective policies and guidelines, and formulate a set of long-term scientific and standardized plans for the protection and inheritance of Jingdezhen ceramic culture. ${ }^{[6]}$ Besides, the government should make timely adjustment according to the actual situation and seek truth from facts. Second, the government should give full play to its leading role and give proper consideration to the protection and inheritance of Jingdezhen, such as increasing financial investment, giving preferential treatment to relevant professionals. Finally, the government should give full play to its official influence, actively promote the political capacity of Jingdezhen ceramic culture, and resolutely crack down on the negative energy transmission of Jingdezhen ceramics culture in the society. For example, a large number of Jingdezhen counterfeit porcelains appear on the market, and the government must mobilize its administrative enforcement and give sanction.

Strengthen the Construction of Professional Colleges and Make Fully Use of College Resources. Ceramic craftsmanship is an ancient traditional art. Due to the changes of the times, the number of relevant personnel is gradually reduced, not to mention the professional craftsmen with superb skills. Therefore, the shortage of talents has become a limiting factor in the protection and 
ceramic culture. To this end, colleges and universities should give full play to the function of personnel training, so that colleges and universities can actively participate in this work.

First of all, colleges and universities should set up related specialties, hire skilled professional porcelain craftsmen to teach, and train specialized talents. Open classes can also be opened to attract people with lofty ideals. ${ }^{[7]}$ Second, colleges and universities should make full use of their academic resources, such as: holding ceramic culture lectures, carrying out ceramic cultural exchanges, etc., and constantly enrich their own ceramic culture and integrate with other areas of ceramic culture. Third, colleges and universities should make full use of their teaching resources, such as: organizing teachers and students to carry out field inspections, exploring ancient kiln sites, and continuing to explore traditional ceramic culture. Finally, colleges and universities should make full use of their research resources, do a good job of collecting, recording, and sorting ceramic culture, and carry out theoretical research to enrich its connotation of ceramic culture.

Give full play to the regulatory role of the market and strictly control the market. The two keys to economic development: national macro-control and market self-regulation, both are indispensable and work together. To protect and inherit Jingdezhen ceramics culture, we must make full use of these two keys and give full play to the market's own regulatory role. Under the encouragement of government policies, enterprises should use the market to give full play to their main role, form distinctive regional brands, and form a healthy competition.

In addition, the vicious competition in the market, the emergence of a large number of counterfeit porcelain, counterfeit trademarks, etc. should not be tolerated. We must not only use the government's supervisory capabilities, but also launch mobilization of civil organizations to suppress the normalization of the Jingdezhen ceramic culture market order.

Actively participate in global market competition and enhance competitiveness. Under the catalysis of modern industrialization, the world is gradually becoming integrated, and economic development has become more globalized. After China joined the World Trade Organization in 2001, it faced greater pressure and challenges on the world stage. Faced with the surge of pressure and challenges, China should actively respond to and actively participate in the competition in the world market and continuously improve its own competitiveness.

Jingdezhen ceramics culture belongs to not only Jiangxi, but also China and the world. Since ancient times, a group of exquisite Jingdezhen porcelain have been exported to foreign countries, evoking the connection between China and the West and becoming an iconic button in the Sino-Western exchanges. Therefore, in the process of protecting and inheriting Jingdezhen ceramic culture, we should establish global awareness and expand its global influence. In actively participating in the competition with the world's intangible cultural heritage, we must not flinch and escape, constantly enhance our own competitiveness, and ultimately come to the fore.

Enhance innovation consciousness and continuously introduce new ideas. Jingdezhen's ceramic art is known for its superb skill and fame, and Jingdezhen is known as the "Ceramic Capital". The core of the ceramic culture of Jingdezhen, which is enduring forever, lies in the constant innovation of artisans. ${ }^{[8]}$ Therefore, under the current frustration of the ceramic culture, in order to protect, inherit and develop the ceramic culture of Jingdezhen, it is not only to explore traditional techniques, but also to combine the requirements of the times, the characteristics of the times, constantly introduce new ones, and take innovation as the core to form continuous new ceramic culture with distinctive features.

Innovation is an inexhaustible motive force for the development of things. The protection and inheritance of traditional ceramic craftsmanship are inseparable from the sense of innovation. Therefore, to promote ceramic culture, we should continue to enhance the sense of innovation, so that the ceramic culture of Jingdezhen not only reflects the level of traditional Chinese technology, but also shows the characteristics of the times. In the end, on the world stage, a new look is revealed, competitiveness is enhanced, and the cultural confidence of the Chinese nation is reflected.

Mobilize all social forces and increase publicity efforts of the mass media. The protection, inheritance, and development of the Jingdezhen ceramic culture are not a one-day rush, nor are they individual or geographical responsibilities, but are the responsibilities of the entire Chinese 
community. Therefore, we must actively mobilize all the strengths of the society and devote ourselves to the arduous task of protecting, inheriting, and developing ceramic culture in Jingdezhen.

To this end, we must make full use of the publicity effect of the mass media and use newspapers and magazines, the Internet, and other means of transmission to produce excellent film and television works. For example, documentaries featuring Jingdezhen's thousands of years of porcelain making development, or TB series with the inheritance of Jingdezhen's porcelain techniques., etc. In addition, we can also actively create a special tourist line. The broadcasting of excellent film and television works and the visit of special tourist lines make the audience or tourists feel the same. Make use of the publicity advantage of the mass media to appreciate the charm of Jingdezhen ceramic culture. ${ }^{[9]}$ Based on this, people can truly appreciate the essence of ceramic culture and be convinced by consciously investing in the great cause of protection and inheritance.

\section{Conclusion}

The Jingdezhen ceramic art has been inheriting for thousands of years. The craftsmen of the past have worked hard to produce a number of breathtakingly beautiful works, forming a ceramic culture of its own characteristics. Nowadays, China is at the critical period of national rejuvenation. Various undertakings are booming. The protection and inheritance of Jingdezhen ceramic culture are also in full swing. Although tremendous achievements have been made in this regard during the previous period, it is still necessary to recognize the necessity and urgency of protecting and inheriting Jingdezhen ceramic culture and recognize its important significance for Jingdezhen, China and even the world. We should continue to sum up our experience and inadequacies from our previous work, so as to further protect and inherit the ceramic culture of Jingdezhen.

\section{Acknowledgements}

Jiangxi University Humanities and Social Science Research Project (2015), Research on Contemporary Art Ceramic Price Evaluation System Based on AHP Method, Project Number: GL1572

\section{References}

[1] X.L Bao X Hu and J He. Jiangxi Social Sciences. 2015(02)

[2] J.Y Sun, L. Wang and Y.CH Li. Anhui Literature (the second half of the month). 2017 (11)

[3] Y.H Wang, W.X Sun. Jingdezhen College of Technology.2014(01)

[4] G.P Mei, J.Y Gan, and Q.Z Zhu. Jiangxi Social Sciences.2014(11)

[5] Y Yan, L Guo. Knowledge Economy. 2015 (10)

[6] B.F Liu .Business Economics.2017(04)

[7] CH Song and L Cheng. Science and Technology Pioneering Monthly.2016(18)

[8] H.D Li and Z.B Fang. Journal of Hebei University(Philosophy and Social Science Edition).2018(02)

[9] N.N Yan, B.F Liu, M.H Tong. Business Economics. 2018(02)

Aiping Zhou, female, (1972 -) associate professor, mainly engaged in public management research Jingdezhen Ceramic Institute 